\title{
Mewujudkan Pemilu 2014 Sebagai Pemilu Demokratis
}

\author{
Budiyono \\ Bagian Hukum Tata Negara Fakultas Hukum Universitas Lampung \\ Email : budiyono.1974@fh.unila.ac.id
}

\begin{abstract}
Abstrak
Pemilu dalam negara demokrasi Indonesia merupakan media atau sarana yang diberikan oleh Negara untuk pergantian pemegang kekuasaan baik dieksekutif maupun legislatif secara damai yang dilakukan secara berkala sesuai dengan prinsip-prinsip yang digariskan konstitusi.Terkait dengan pentingnya pemilu dalam proses demokratisasi di suatu Negara, maka penting untuk mewujudkan pemilu yang memang benar-benar mengarah pada nilai-nilai demokrasi dan mendukung demokrasi itu sendiri artinya pemilu yang dapat menyalurkan dan mewujudkan aspirasi suara rakyat dalam berbagai kebijakan penyelenggaran Negara bukan sekedar pemberian legitimasi pemegang kekuasaan dengan begitu keberhasilan pemilu yang dilaksanakan merupakan kemenangan besar artinya kemenangan itu milik semua komponen bangsa bukan milik kemenangan peserta pemilu. Untuk mencapai tujuan tersebut pemilu harus dilaksanakan dengan menurut asas-asas tertentu. Asas-asas itu mengikat mengikat keseluruhan proses pemilu dan semua pihak yang terlibat, baik penyelenggara Negara, peserta, pemilih, bahkan pemerintah. UUD 1945 menentukan, pemilu harus dilaksanakan secara langsung, umum, bebas, rahasia, jujur, dan adil
\end{abstract}

Kata kunci : pemilu dan pemilu demokratis.

\section{Pendahuluan}

Alinea keempat pembukaan UUD 1945, yang menyatakan bahwa Kemerdekaan Kebangsaan Indonesia terbentuk dalam "susunan Negara Republik Indonesia yang berkedaualatan rakyat, " dan Sila keempat Pancasila, merupakan bentuk pengakuan atau pilihan bangsa Indonesia mengenai sistem politik yang akan dijalankan dalam berbangsa dan bernegara yakni pengakuan atas kedaulatan rakyat (demokrasi). Pengakuan terhadap kedaulatan rakyat tersebut dipertegas dalam Pasal 1 ayat (2) UUD 1945 hasil perubahan ketiga " kedaulatan berada ditangan rakyat dan dilaksanakan menurut UndangUndang Dasar."
Mekanisme pelaksanaan kedaulatan rakyat adalah melalui pemilihan umum (pemilu) artinya pemilu merepresentasikan simbol bahwa rakyat adalah pemegang kedaulatan.

UUD 1945 secara tegas telah menentukan adanya pemilihan umum (pemilu) yaitu Pasal 19 ayat (1) “ Anggota Dewan Perwakilan Rakyat dipilih melalui pemilihan Umum". Selanjutnya Pasal 22 E ayat (1) Pemilihan Umum dilaksankan secara langsung, umum, bebas, rahasia, jujur, dan adil setiap lima tahun sekali. Pilihan dengan sistim kedaulatan rakyat (demokrasi) melalui pemilu dimaksudkan dalam rangka untuk mencapai tujuan nasional, yaitu melindungi segenap bangsa Indonesia dan tumpah darah Indonesia, memajukan kesejateraan 
umum, mencerdaskan kehidupan bangsa, dan ikut serta melaksanakan ketertiban dunia. Pendiri bangsa berkeyakinan bahwa pencapain tujuan nasional tersebut hanya dapat dicapai melalui kemerdekaan kebangsaaan yang terbentuk melalui sistim demokrasi. Demokrasi adalah manifestasi keyakinan akan kemerdekaan dan kebebasan setiap insan manusia yang dalam konteks beregara menjelma menjadi pengakuan atas kedaulatan rakyat.

Pemilu sebagai bentuk paling nyata dari kedaulatan yang berada ditangan rakyat serta wujud paling konkrit partisipasi rakyat dalam penyelenggaraan Negara. Pemilu mengimplikasikan terselenggaranya mekanisme pemerintahan secara tertib, teratur dan damai serta lahirnya masyarakat yang dapat menghormati dan menghargai perbedaan pendapat. Disamping itu lebih lanjut Pemilu diharapkan melahirkan suatu masyarakat yang kritis, dalam arti bersifat selektif atau biasa memilih yang terbaik menurut keyakinannya., artinya rakyat memilih seseorang untuk mewakilinya dalam rangka keikutsertaan rakyat dalam penyelenggaraan pemerintahan negara,sekaligus pemilu sebagai sebuah proses seleksi terhadap lahirnya pemimpin dalam rangka perwujudan demokrasi diharapkan menjadi representasi dari rakyat, karena pemilu merupakan suatu rangkaian kegiatan politik untuk menampung serta mewujudkan kepentingan masyarakat yang dirumuskan dalam berbagai bentuk kebijaksanaan.

Pemilu dalam negara demokrasi Indonesia merupakan media atau sarana yang diberikan oleh Negara untuk pergantian pemegang kekuasaan baik dieksekutif maupun legislatif secara damai yang dilakukan secara berkala sesuai dengan prinsip-prinsip yang digariskan konstitusi. Prinsip-prinsip dalam pemilihan umum yang sesuai dengan konstitusi antara lain prinsip kehidupan ketatanegaraan yang berkedaulatan rakyat (demokrasi) ditandai bahwa setiap warga negara tanpa membeda-bedakan baik atas dasar ekonomi, keturunan, pandangan politik atau keyakinan berhak ikut aktif dalam setiap proses pengambilan keputusan kenegaraan. Pemilu merupakan kegiatan politik yang sangat penting dalam proses penyelenggaraan kekuasaan dalam sebuah negara yang menganut prinsip-prinsip demokrasi. Artinya kekuasaan yang lahir melalui pemilihan umum adalah kekuasaan yang lahir dari bawah menurut kehendak rakyat dan dipergunakan sesuai dengan keinginan rakyat.

Terkait dengan pentingnya pemilu dalam proses demokratisasi di suatu Negara, maka penting untuk mewujudkan pemilu yang memang benar-benar mengarah pada nilainilai demokrasi dan mendukung demokrasi itu sendiri artinya pemilu yang dapat menyalurkan dan mewujudkan aspirasi suara rakyat dalam berbagai kebijakan penyelenggaran Negara bukan sekedar pemberian legitimasi pemegang kekuasaan dengan begitu keberhasilan pemilu yang dilaksanakan merupakan kemenangan besar artinya kemenangan itu milik semua komponen bangsa bukan milik kemenangan peserta pemilu . Untuk mencapai tujuan tersebut pemilu harus dilaksanakan dengan menurut asas-asas tertentu. Asas-asas itu mengikat mengikat keseluruhan 
proses pemilu dan semua pihak yang terlibat, baik penyelenggara Negara, peserta, pemilih, bahkan pemerintah. UUD 1945 menentukan, pemilu harus dilaksanakan secara langsung, umum, bebas, rahasia, jujur, dan adil

\section{Pembahasan}

Pada tahun 2009, bangsa
Indonesia menyelenggarakan perhelatan akbar dalam kehidupan berdemokrasi yaitu pemilhan umum. Meskipun ditemukan sejumlah masalah salah satu diantaranya adanya sejumlah warga Negara yang terpaksa tidak dapat menggunakan hak pilihnya karena kekacauan administratif DPT. Padahal salah satu tujuan pendidikan politik dalam konteks pemilu yang lebih bersifat nyata dan rasional adalah meningkatnya partisipasi rakyat dalam pemilihan (electoral participation ). Kekurangan dan kelemahan tersebut

Selanjutnya pada tahun 2014 kita akan mengadakan pemilu yang ke empat pada masa reformasi, pemilu 2014 diharapakan berjalan dengan baik dan mendatangkan pengaruh yang positif bagi perubahan bangsa Indonesia, sehingga pemilu 2014menjadi kemenganan bangsa Indonesia dimana pemilu 2014 dapat mewujudkan pemerintahan yang baik, pemerintahan yang berwibawa, pemerintahan yang bersih serta pemerintahaan yang bekerja untuk kepentingan rakyatnya. Sebagaimana Tujuan penyelenggaraan pemilu menurut Jilmly Asshiddiqie itu ada empat, yaitu ${ }^{1}$ :

${ }^{1}$ Jimly Asshiddiqie, Pengantar Ilmu Hukum Tata Negara, jilid II, SeKretariat Jenderal dan Kepaniteraan Mahkamah Konstitusi RepubliK Indonesia, Jakarta, 2006, hlm, 175
1. Untuk memungkinkan terjadinya peralihan kepemimpinan pemerintah secara tertib dan damai

2. Untuk memungkinkan terjadinya pergantian pejabat yang akan mewakili kepentingan rakyat dilembaga perwakilan

3. Untuk melaksanakanprinsipprinsp kedaulatan rakyat dilembaga perwakilan

4. Untuk melaksakan prinsip hakhak asasi warga Negara.

Secara normatif, penyelenggaraan Pemilu di Indonesia memunyai empat (4) tujuan pokok, yaitu; pertama, untuk memilih wakil rakyat dan wakil daerah, kedua, untuk membentuk pemerintahan yang demokratis, bersih, dan kuat, ketiga, memperoleh dukungan rakyat, ke-empat, mewujudkan tujuan nasional sebagaimana diamanatkan dalam pembukaan Undang-Undang Dasar Negara Republik Indonesia Tahun 1945.

Pemilu yang merupakan sarana mewujudkan prinsip kedaulatan rakyat, dimana pemilu rakyat tidak hanya memilih orang yang akan menjadi wakilnya dalam penyelenggaran Negara, tetapi juga memilih program yang menjadi kebijakan pemerintahan selanjutnya.oleh karena itu, tujuan pemilu adalah terpilihnya wakil rakyat dan terselenggaranya pemerintahan yang sesuai dengan pilihan rakyat. Pemilu yang tidak mampu mencapai tujuan itu hanya akan menjadi mekanisme pemberian legitimasi bagi pemegang kekuasaan Negara. Untuk mencapai tujuan pemilu sesuai dengan yang diharapakan maka UUD 1945 sudah menegaskan prisip-prinsip pemilu dalam Pasal 22 E ayat (1)“ pemilihan 
umum dilaksanakan secara langsung, umum, bebas, rahasia, jujur, dan adil setiap lima tahun sekali."Berdasarkan ketentuan tersebut dapat dilihat bahwa penyelenggaraan pemilu merupakan pelaksanaan Pancasila dan UUD 1945 yang bukan merupakan sekedar hak tetapi sekaligus merupakan kewajiban dan tanggung jawab setiap warga Negara untuk mensukseskannya.

Pemilu yang merupakan sebuah mekanisme memperbarui perjanjian sosial warga Negara dan pembentukan kelembagaan negara secara demokrasi. Hasil pemilu menentukan jalannya pemerintahan lima tahun berikutnya sesuai dengan aspirasi masyarakat. Keberhasilan penyelenggaran pemilu banyak dipengaruhi oleh peraturan perundang-undangan yang mengaturnya, pemahaman, kesadaran dan tanggung jawab masyarakat, partai politik, dan penyelenggara pemilu.

Peraturan perundang-undangan dalam penyelenggaraan pemilu harus dapat benar-benar menjadi media perwujudan kedaulatan rakyat, sesuai dengan asas-asas penyelenggaraan pemilu yang telah digariskan oleh UUD $1945^{2}$. UU penyelenggaran pemilu dimaksudkan untuk memberikan landasan hukum penyelenggaran pemilu yang demokratis, dengan parameter keterwakilan penduduk dan keterwakilan daerah, serta adanya pertanggungjawaban wakil rakyat terhadap pemilihnya. Untuk mewujudkan hal tersebut perlu diatur sistem pemilihan umum dalam pemilihan wakil rakyat. Dalam penentuan sistem pemilu yang harus

${ }^{2}$ Pasal 22 E UUD 1945 diperhatikan adalah ketentuan yang ada dalam UUD 1945 dan kondisi atau keberagaman bangsa Indonesia. ${ }^{3}$

Pengakuan kedaulatan rakyat dalam UUD 1945 merupakan dasar pertimbangan dalam penentuan sistem pemilihan umum. Pengakuan atas kedaulatan rakyat tersebut mengharuskan pemerintahan yang terbentuk adalah pemerintahan yang sesuai dengan aspirasi rakyat. Untuk mewujudkan hal tersebut sistem pemilu yang dipilih harus mampu mewujudkan kehendak rakyat, baik dari sisi wakil rakyat atau pejabat yang dipilih maupun kebijakankebijakan yang dilakukan oleh wakil rakyat atau pejabat tersebut. Dari kondisi atau keberagaman bangsa Indonesia yang perlu diperhatikan adalah keanegragaman politik, budaya, maupun agama serta katareteristik wilayah, baik dari sisi populasi maupun sumber daya alam. Sehingga keanekaragaman tersebut terwakili tanpa diskriminasi sehingga pemilu bisa menjadi perekat intergrasi nasional sesuai dengan tujuan Negara Indonesia .

Partispasi politik masyarakat dalam pemilu juga sangat penting untuk mengukur keberhasilan penyelenggaran pemilu atau kualitas demokrasi. Semakin banyak partisipasi politik masyarakat dalam pemilu maka akan lebih baik karena partispasi menunjukan bahwa masyarakat mengikuti dan memahami pemilu dan ingin diri dalam kegiatan pemilu tersebut, namun sebaliknya apabila tingkat partisipasi politik masyarakat menurun atau rendah sebagai tanda yang kurang baik, ini menunjukan masyarakat apatis terhadap masalah

\footnotetext{
${ }^{3}$ Jenedjri M. Gaffar, Politik Hukum Pemilu, Konstitusi Press, Jakarta,2012, hlm 38

${ }^{4}$ Ibid, hlm 39
} 
kenegaraan dalam hal ini pemilu. Penurunan partisipasi politik masyarakat ini dapat disebabkan adanya kekecewaan dari masyarakat dimana masyarakat mengunkan hak pilih atau tidak, tidak membawa perubahan yang signifikan terhadap kehidupan mereka. Pemahaman, kesadaran, dan tanggungjawab masyarakat (rakyat) dalam partisipasi penyelenggaran pemilu adalah sangat penting karena pemilu akan menentukan masa depan bangsa. Pemilu bukan sekedar hak tetapi juga kewajiban atau tanggungjawab masyarakat untuk mensuksueskannya.

Membangun

partispasi masyarakat dalam pemilu adalah tanggungjawab partai poltik. Karena partai politik adalah organisasi yang dibentuk dengan tujuan untuk memperjuangkan cita-cita perjuangan dan membela kepentingan politik anggota, masyartakat, bangsa dan Negara, serta memelihara keutuhan Negara Kesatuan Republik Indonesia berdasarkan Pancasila dan UUD 1945. Peran konstitusional partai politik dalam pemilu adalah ditegaskan dalam Pasal 6 A ayat (2) memberikan peran kepada partai politik dan gabungan partai politik peserta pemilu mengusulakan pasangan presiden dan wakil presiden dan Pasal 22 E ayat (3) menyatakan bahwa peserta pemilu DPR dan DPRD adalah Partai Politik.

Berdasarkan ketetuan UUD
1945 tersebut Partai politik
mempunyai posisi (status) dan
peranan (role) yang sangat penting
dalam setiap pemilu. Partai politik
memainkan peranan dalam
menyeleksi calon-calon anggota
legislatif dalam pemilu. Peranan

partai politik tersebut diwujudkan dengan melakukan mekanisme rekrutmen politik yang dapat menghasilkan pelaku-pelaku politik yang berkualitas di masyarakat, karena salah satu tugas dalam rekrutmen politik adalah bagaimana paratit politik yang ada dapat menyediakan kader-kader partai politik yang berkualitas untuk duduk di lembaga legislatif maupun eksekutif.

Partai politik dituntut harus mampu melahirkan anggota-anggota legislatif yang berkualitas dan mengerti akan segala aspirasi masyarakat. Untuk menciptakan kader-kader yang berkualitas tersebut, partai politik harus menjalankan fungsinya dengan baik, terutama fungsi rekrutmen politik. Dengan melakukan rekrutmen atau seleksi terhadap kader-kaderyang akan duduk dilembaga Negara dengan baik, teratur dan terdencana sehingga menghasilkan kader-kader yang berkualitas dapat meningkatkan meningkatkan partisipasi politik masyarakat pemilu. Karena masyarakat melihat atau mempunyai harapan terhadap pemilu karena disediakan kader-kader yang berkualitas yang layak dipilih sehinnga dapat menyampaikan aspirasi mereka yang diwujudkan dalam pembuatan dalam produk legislasi dan kebijakan publik.

$$
\text { Selanjutnya }
$$

dalam mewujudkan pemilu demokratis sesuai dengan pancasila dan UUD1945 adalah faktor penyelenggara Pemilu, UUD 1945 Pasal 22 E ayat (5) menyatakan bahwa pemilihan umum diselenggarakan oleh komisi pemilihan umum yang bersifat nasional, tetap dan mandiri. Ketentuan tersebut tidak menyebut 
nama satu lembaga penyelenggara pemilu secara spesifik hanya sifat penyelenggara pemilu, yaitu nasional, tetap, dan mandir. Ketentuan konstitusional tersebut harus diwujudkan dalam kelembagaan penyelenggaraan pemilu.

Dalam perkembanganya ketentuan konstitusional atas pengertian "suatu komisi pemilihan umum" sebagai penyelenggara pemilu ditafsirkan melalui Putusan MK Nomor 11/PUU-VIII/2010 yang menguji Undang-Undang Nomor 22 Tahun 2007 tentang Penyelenggaran Pemilu. Menurut putusan tersebut, frasa "suatu komisi pemilihan umum" dalam UUD 1945 tidak merujuk kepada sebuah nama intitusi, melainkan kepada fungsi penyelenggaran pemilu yang bersifat nasional, tetap, mandiri. Dalam kesatuan penyelenggar pemilu tidak hanya dilaksanakan oleh Komisi Pemilihan Umum (KPU), melainkan juga termasuk pengawasan pemilu yang dijalankan oleh Badan Pengawasan Pemilihan Umum (Bawaslu), Keduanya merupakan satu kesatuan fungsi penyelenggaran pemilu.

Dalam konteks Pemilu KPU sebagai penyelenggara yang mandiri, sangat diperlukan demi terlaksanaya pemilu yang memenuhi asas luber dan jurdil. selain itu pemilu juga memerlukan pengawasan sehingga penyelenggara pemilu dapat selalu dijaga agar memenuhi asas luber dan jurdil. Tanpa adanya pengawasan dikhawatirkan dalam penyelenggaran pemilu terdapat penyimpangan-penyimpangan yang dapat mengancam prinsip-prinsip luber dan jurdil yang sudah diamanatkan dalam UUD 1945 sehingga mengancam kehidupan demokratis. Adanya pengawasa nmerupakan komponen untuk menentukan keberhasilan penyelenggaran pemilu selain terjaminya penyelengaraan pemilu secara mandiri dan independen sekaligus terciptanya mekanisme cheks and balances.

Salah satu sifat peneyelenggaran pemilu adalah sifat mandiri yang diartikan bebas dari segala bentuk pengaruh atau intervensi pihka lain, yang dapat mengurangi penyelenggaran pemilu yang luber dan jurdil. Kemandirian ini sangat penting karena hakekatnya pemilu adalah sebuah kompetisi dimana kemungkinan adanya upaya mempengaruhi kinerja penyelengaa pemilu hanya dengan sebuah kemandiriaan penyelengara-lah, penyelenggaraan pemilu yang jujur dan adil dfapat terjamin.

Upaya menjamin kemandirian penyelengara pemilu dilekukan sejak proses rektrutmen, pelaksanaan tugas, hingga pertangungjawaban. Mekanisme dan proses rekrutmen harus dapat menjamin bahwa anggota kelak dapat bertindak secara mandiri sesuai dengan fungsi yang dijalankan. Meskipun proses terakhir pemilihan dilakukan secara politis, anggota KPU dan Bawaslu terpilih harus tetap mampu menjaga independensi dan integritas. KPU dan Bawaslu harus menjalankan tugasnya sebagai penyelenggara pemilu yang mandiri dan profesional untuk menyelenggarakan pemilu 2014 yang jujur, adil, demokratis, berkualitas, dan lebih baik sesuai dengan amanat UUD 1945. Anggota KPU dan Bawaslu harus bekerja secara profesional, cekatan, dan bersih sehingga dapat segera memulihkan kepercayaan publik terhadap lembaga penyelenggara 
pemilu. KPU dan Bawaslu agar bekerja secara terbuka, partisipatif, dan mengajak seluruh elemen masyarakat untuk terus mengawasi dan mengkritisi KPU dan Bawaslu agar pemilu 2014 dapat terselenggarakan sesuai dengan harapan masyarakat.

\section{Simpulan}

UUD 1945 telah menegaskan bahwa penyelenggara pemilu yang demokratis harus berdasarkan prinsip-prinsip langsung, umum, bebas, rahasia,jujur dan adil. Prinsipprinsip tersebut harus terwujud dalam peraturan perundangundangan yang mengaturnya, serta adanya pemahaman, kesadaran dan tanggung jawab masyarakat, partai politik, dan penyelenggara pemilu. Sehingga keberhasilan Pemilu tahun 2014 adalah suatu kemenangan bersama bangsa Indonesia yang lebih penting daripada kemenangan peserta pemilu.

\section{Daftar Pustaka}

Khairul Fahmi, Pemilihan Umum Dan Kedaulatan Rakyat, PT Rajagrafindo Persada, Jakarta, 2012

Jimly Asshiddiqie, Pengantar Ilmu Hukum Tata Negara, jilid II, Sekretariat Jenderal dan Kepaniteraan Mahkamah Konstitusi RepubliK Indonesia, Jakarta, 2006,

Jenedjri M. Gaffar, Politik Hukum Pemilu, Konstitusi Press, Jakarta, 2012.

Mahfud MD, Dasar dan Srtuktur Ketatanegaraan Indonesia, Rineka Cipta, Jakarta, 2001 